UDK 871.6

Jurij Snoj

Znanstvenoraziskovalni center SAZU, Ljubljana

Scientific Research Centre of the Slovenian Academy of Sciences and Arts, Ljubljana

\title{
Glasbeno delo in njegove interpretacije
}

\author{
A Musical Work and Its Performances
}

Posveçeno Janezu Lovšetu

Ključne besede: interpretiranje glasbe, historična avtentičnost, glasbeno delo, glasbeni pomen, platonizem $v$ glasbi, estetika glasbe

\section{POVZETEK}

$\mathrm{Na}$ osnovi nekaterih $\mathrm{v}$ zadnjih dveh desetletjih objavljenih razprav o glasbenem interpretiranju (T. C. Mark, G. Tomlinson, P. Kivy, R. Scruton) so izpeljane in obrazložene tri teze: 1 . Razlika med glasbo in neinterpretativnimi umetnostmi (literatura, slikarstvo itd.) ni tako velika, kot se navadno misli. Interpretiranje je umetnosti neodtujljivo in razloček med literaturo in drugimi neinterpretativnimi umetnostmi na eni strani in glasbo na drugi je, da je ob literarnem delu bralec tudi svoj lastni interpret, medtem ko je v glasbi interpretacija zaupana profesionalnim izvajalcem. 2. Izvajalsko gibanje "zgodnje glasbe" je odkrilo izvajalske prakse in vzpostavilo standarde brez katerih si danes ni mogoče predstavljati interpretiranja glasbe izpred druge polovice 18 . stol. A kot meni P. Kivy, iskanje avtentičnega pomena glasbenega dela ni zamenljivo $\mathrm{z}$ rekonstruiranjem domnevne historično avtentične izvedbe. $\mathrm{Z}$ ozirom na naravo glasbenega dela je njegov notranji smisel onstran njegove historične zvočne podobe. 3. T. C. Mark ugotavlja, da je izvedba intencionalni akt. Kot taka ni niti predvidljiva niti ponovljiva. Ob neodtujljivi inspiracijski svobodi pri interpretiranju umetnosti zgodovina izvedb danega dela ni nujno pot k pomenu, ki ga je videl skladatelj; enako lahko vodi tudi stran od skla-
Keywords: performance, historical authenticy, musical work, musical meaning, Platonistic concept of music, aesthetics of music

\section{SuMMARY}

Proceeding from some discussions of the topic from the last two decades (T. C. Mark, G. Tomlinson, P. Kivy, R. Scruton) the following three theses are developed and proposed: 1 . The differences between music and non-interpretative arts (literature, painting etc.) are not as substantial as generally assumed. It is essential to art in general that it allows and even calls for interpretation. Thus, the disparity between literature (and other non-interpretative arts) on the one hand and music on the other appears to be limited to the fact that in the former the reader assumes the role of her or his own interpreter as well, whereas in the latter it is to professionals that performing and interpreting is entrusted. 2 . The early music movement has discovered practices and set up standards without which it is nowadays inconceivable to perform musical works from the time before the middle of the 18th century. However, according to P. Kivy, searching for authentic meaning of a musical work cannot be confused with reconstructing its hypothetical, historically authentic performance. Taking into account the nature of a musical work, its intrinsic meaning necessarilly lies beyond its historical sound image. 3. Following T. C. Mark, a performance should be considered as an intentio- 
dateljeve resnice, $v$ še neizkušena in neznana področja. Takšno gledanje ni združljivo s platonističnim pojmovanjem izvedb kot instanc, primerkov glasbenega dela, obstajajočega kot ideja. nal act. As such it is unpredictable as well as irrecoverable. However, because of the inspirational freedom necessary in interpreting the works of art, the history of performances of a given musical work cannot be necesarilly understood as approaching the alleged original, composer's meaning of the work; it may equally lead away from it, proceeding way into not yet experienced areas. Such a view cannot be reconciled with the Platonistic conception of performances as instances or tokens of a universal.

\section{Problem}

Ali je možno, da zaigrana kompozicija, zapeta melodija ne bi bila interpretirana? Zdi se, da ne. Dirigent, pevec, instrumentalist, tudi če ima pred sabo skladateljevo partituro in tudi če zvesto upošteva vse skladateljeve napotke, ne more ravnati drugače, kot da si zamisli glasbeni smisel igranega dela; o glasbenem delu, četudi je natančno določeno z glasbenim zapisom, si mora ustvariti lastno predstavo, katere uresničitev je interpretativni akt. A kot je dobro znano, so si interpretacije lahko tudi zelo različne; omejujoč se na zunanje in slišno, se razločujejo $\mathrm{v}$ tempu, dinamiki, pa tudi $\mathrm{v}$ zvočnosti $\mathrm{z}$ ozirom na uporabljena glasbila in načine igranja nanje. Vsakdo, ki se ukvarja $z$ glasbo, se tako ali drugače sooča s problemom glasbenega interpretiranja: Poslušalec zaznava različne interpretacije iste kompozicije; nekatere so mu lahko ljube, druge odklanja; skladatelj presoja, kaj so njegove zamisli postale $\mathrm{v}$ rokah drugih; interpret se lahko zave, da je isto kompozicijo mogoče različno interpretirati; glasbeni zgodovinar lahko presoja, ali so interpretacije zgodovinsko ustrezne ali ne.

Že tako preprost in prvinski razmislek o glasbenem interpretiranju, kakršen je pravkar podani, uvaja vrsto pojmov in odnosov med njimi. Na eni strani je samo glasbeno delo, kompozicija, ki jo je ustvaril znani ali neznani avtor. Navadno si predstavljamo, da ima kompozicija svojo razpoznavno in tudi nespremenljivo identiteto, tisto, kar jo določa. Kompozicija je berljiva in dostopna prek skladateljeve partiture, ki je tak ali drugačen zapis kompozicije; a kot nakazuje že besedna zveza "zapis kompozicije", partitura ni istovetna $\mathrm{z}$ glasbenim delom samim. Glasbeno delo in zapis, ki sestoji iz določenih znakov, nista isto. Nadalje je tu pojem izvedbe, poustvaritve, interpretacije. Ta izhaja iz partiture, skladateljevega zapisa in v partituri vsebovanih napotkov interpretu. Vendar: če naj poslušalec dojema igrano in poslušano glasbo, mora ta imeti svoj pomen; smisel, ki mora biti razviden glasbenemu intelektu poslušalca. To pomeni, da interpretacija ne more biti le mehanična "izvedba" skladateljeve zamisli, proizvodnja v partituri zapisanih znakov; če naj bo dojemljiva, mora tudi sama poiskati smisel tistega, kar posreduje partitura. Tako je v razmišljanje o glasbenem interpretiranju treba uvesti tudi pojem glasbenega smisla, pomena, ki naj bi ga imela interpretirana skladba. ${ }^{1}$

Na prvi pogled bi se zdelo, da je vse skladateljsko hotenje izraženo v partituri, vendar ni nujno tako. Partitura ne govori le $s$ tistim, kar je $v$ njej izrecno napisano, pač pa tudi s tistim, kar glasbeni zapis predpostavlja, ne da bi izrecno izrazil. Zapisovanje glasbe ima sicer strnjeno zgodovino, vendar tako dolgo, da se je v njenem teku tisto, kar je bilo na

\footnotetext{
Kot si ni težko predstavljati, je "smisel" glasbenega dela pojem, ne pa nujno tudi vsebinski smisel, saj si je mogoče misliti tudi takšne kompozicije oz. interpretacije, ki je njihov smisel ravno v odsotnosti smisla.
} 
njenem začetku, preobrazilo do nerazpoznavnosti. A tudi glasbena zvočnost, glasbeni instrumentarij in načini izvajanja so se in se ves čas spreminjajo. To pomeni, da je tisto, kar je podano v skladateljskem zapisu, treba brati in razumeti v ustreznem glasbenozvočnem in glasbenoizvajalskem kontekstu. Ko je Bach naslavljal svoje zbirke z izrazom "Clavier Ubung", je imel v mislih instrumente s tipkami svojega časa, gotovo pa ne sodobnega klavirja. Ko je komponiral kantate, si je morda zamišljal ideal, ki bi ga lahko dosegli izvajalci njegovega časa. Vedel je, kako bodo frazirali in kakšne tempe bodo izbirali in morda so $\mathrm{v}$ njegovih partiturah izvajalske oznake za fraziranje in hitrost tudi zato tako redke. Iz vsega tega je razvidno, da je glasbenim zapisom treba dodati tudi pojem njihovega zvočnega in izvajalskega konteksta, v katerem so nastali.

Ob prikazanih pojmih se postavlja vprašanje, kaj natančneje so in kakšne so možne povezave med njimi. Kaj je glasbeno delo in kaj je njegova identiteta: Je določena le $s$ tistim, kar je zapisano v partituri? Je tonska struktura kompozicije sama po sebi že jamstvo njene identitete, ali pa je ta brez zvočnega in izvajalskega konteksta partiture izgubljena? Kako si je mogoče razlagati dejstvo, da so zapisi starejše glasbe, gledano z očmi kasnejšega časa, pomanjkljivi, da nimajo interpretativnih oznak? Ali te oznake manjkajo zgolj zato, ker so bile glede na izvajalske konvencije in navade okolja nepotrebne? To bi pomenilo, da je v Bachovem času interpret Bachove zbirke Klavierübung III vedel, kateri tempo in katero registracijo zahteva uvodni preludij, čeprav Bachov zapis ne vsebuje ne enega ne drugega. Je glasbeni smisel kompozicije dostopen in možen le znotraj zvočnega in izvajalskega konteksta partiture? Strogo vzeto bi to pomenilo, da na sodobnem klavirju ni mogoče podati glasbenih precioznosti, tako značilnih za F. Couperina. Nadalje: Je ob dejstvu, da se glasbena dela različno izvajajo, glasbeni smisel kompozicije en sam, in če je tako, kateri je? Ali tisti, ki si ga je zamislil skladatelj in ga je treba izluščiti iz pomanjkljivih zapisov? Ali je možno, da bi imela ena kompozicija več smislov, ki jih je mogoče videti $v$ različnih interpretacijah, ali pa je treba te vrednostno razvrstiti $z$ ozirom na to, kako blizu so prvotnemu, skladateljevemu smislu skladbe? Ali so različne interpretacije vsebovane že v skladateljevi zamisli skladbe, $v$ glasbenem delu? To bi pomenilo, da je vse, kar so si zamislili izvajalci Chopinove Etude v As-duru, zaobseženo in predvideno že v njej sami kot glasbenem delu; imela bi toliko različnih obrazov in smislov, kolikor ima različnih izvedb; njeno umetniškost bi bilo mogoče videti prav v tem, da omogoča različna razumevanja, veličino njenega skladatelja pa $v$ tem, da jih je dopustil in morda celo predvidel. Je potemtakem zgodovina interpretiranja te kompozicije odkrivanje mnogoobraznosti njenega genialnega avtorja? A če je tako, kaj je identiteta glasbenega dela samega in $s$ čim je določeno?

Prikazana vprašanja obstojijo vsaj od tistega časa dalje, ko so se pojavili prvi glasbeni zapisi. Najstarejši, iz okoli leta 900 izhajajoči zapis graduala Ex Sion species omogoča vprašanje razmerja med njim in dejanskim petjem imenovanega speva, ki v 9. stol. gotovo ni bil znan le v Sankt Gallnu, od koder izvira njegov najstarejši zapis. Na podoben način je mogoče razmišljati o razmerju med zapisi madrigalov v Caccinijevem tisku iz leta 1602, ki ima dolg, izvajalcem namenjen uvod, in Caccinijevimi lastnimi izvedbami v zbirki natisnjenih skladb. V tem smislu je vprašanje glasbenega interpretiranja staro. Razpravljanje o njem pa je mnogo mlajše in občutneje se je razmahnilo šele v zadnjih desetletjih. Pred 19. stol. se je v prvi vrsti izvajala le vsakokratna sodobna glasba in tako med glasbenimi zapisi in zvočnim ter izvajalskim kontekstom ni bilo občutnejših razhajanj. Ta so se začela pojavljati šele v 19. stol., in sicer s tem, da so opusi nekaterih skladateljev, ki jim je že sodobnost pripisala vsesplošno veljavnost, tako kot Beethovnovemu, ostali v glasbenem življenju vseskozi prisotni: ob spreminjajočih se izvajalskih konvencijah, ob spreminjajočem se izvajalskem in zvočnem kontekstu je po določenem času nujno priš- 
lo do razhajanj z izvajalskim in zvočnim kontekstom časa njihovega nastanka in zavest o nastalem razkoraku je nujno privedla do vprašanja, kako naj bi se interpretirali.

Še zlasti pa se je razpravljanje o glasbenem interpretiranju pojavilo ob ponovnem oživljanju tiste glasbe, ki je zapadla popolni pozabi. Raziskovanje dejanskega glasbenega življenja preteklih obdobij je, kot je dobro znano, privedlo do odkritij zvočnih svetov preteklosti, do pojmovanja zgodovinsko pravilnega, historično avtentičnega interpretiranja in do izvajalskega gibanja "zgodnje glasbe". ${ }^{2}$ Gotovo je bil Bachov opus eden tistih, ki so doživeli največ poskusov zgodovinsko točnega interpretiranja. A težnjo po zgodovinsko verodostojnem interpretiranju moremo videti že $v$ delu benediktincev iz Solesmesa, ki so sredi 19. stol. na osnovi študija najstarejših nevmatskih rokopisov skušali restavrirati avtentično podobo gregorijanskega korala. Morda je prav nerazvidnost glasbenega smisla glasbe srednjeveških in drugih oddaljenih obdobij privedla do pričakovanja, da se bo glasbeni smisel razkril ob rekonstrukciji zgodovinsko avtentične zvočnosti: šele ko bo znano, kako so se gregorijanski spevi dejansko slišali, naj bi se razkril njihov pravi glasbeni smisel. V takšnem miselnem okolju je mogoče razumeti tudi tisto pogosto citirano izjavo, ki je privedla do gregorijanske semiologije. ${ }^{3}$ Porast razpravljanja o vprašanjih glasbenega interpretiranja pa je nazadnje tudi posledica razgibanega glasbenega življenja. Dejstvo, da je danes istočasno prisotna glasba mnogih zgodovinskih obdobij in okolij, ki se igra na različne načine, da obstojijo različne razvijajoče se interpretativne smeri in da se pojavljajo vedno nove in drugačne interpretacije že mnogokrat zaigranih in premišljenih del in opusov, je moralo privesti do teoretičnega razpravljanja o tem, kaj je glasbena interpretacija in v kakšnem odnosu je do interpretiranega dela.

Razpravljanje o glasbenem interpretiranju ni le enovrstno in pogled po literaturi pokaže vsaj tri glasboslovna področja, ki so jim v središču zanimanja vprašanja glasbenega interpretiranja. Historično avtentično izvajanje je možno le na osnovi ustreznih zgodovinskih raziskav in tako je bilo $\mathrm{v}$ zadnjih desetletjih objavljeno nepregledno število raznovrstnih izsledkov v zvezi z glasbeno prakso preteklih stoletij. Te raziskave se osredotočajo tako na zgodovino izdelovanja instrumentov, na vprašanje njihovih uglasitev, na akustiko zgodovinskih prostorov, na sestave izvajalskih skupin, na izvajalske in pevske tehnike, prav tako pa tudi na vprašanja, kakšno je bilo v danem okolju lokovanje, fraziranje, okraševanje. Vse to glasbenozgodovinopisno raziskovanje, katerega izsledki omogočajo branje glasbenih zapisov v njihovih zvočnih in izvajalskih kontekstih, si postavlja za cilj zgodovinsko čimbolj verno rekonstruiranje glasbe, kakršna je $v$ preteklosti $v$ resnici zvenela. ${ }^{4} S$ povsem drugačnimi vprašanji $\mathrm{v}$ zvezi $\mathrm{z}$ interpretiranjem pa se ukvarja psihologija glasbe. Kolikor je mogoče soditi iz površinskega pregleda, je usmerjena predvsem pozitivistično. Tako se posveča vprašanjem tehnične dovršenosti instrumentalistov, zlasti pianistov, in z vprašanji procesov, preko katerih se glasbeno doživljanje pretvarja $\mathrm{v}$ telesne gibe in zvok; nadalje presoja konstantnost oz. spremenljivost časa interpretacije danega dela pri istem interpretu; raziskuje naravo sodelovanja in interakcije med dvema istočasno nastopajočima interpretoma. Ukvarja se tudi $z$ vprašanji interpretativne izraznosti in med drugim ugotavlja: dejstvo, da isti interpret isto delo enako izvaja, ne pomeni, da si je zapomnil tempo, dinamiko itd., pač pa, da izhaja iz vedno iste

2 O zgodovini historično avtentičnega izvajanja se je mogoče poučiti v delu: Haskell, HarRY, The Early Music Revival, London 1988; zanimiva je tudi Brownova razprava: Brown, Howard M., "Pedantry or Liberation? A Sketch of the Historical Performence Movement", Authenticity and Early Music, ur. Nicholas KenYon, Oxford 1988, str. 27-56.

3 Eugène Cardine: "Ali ni za glasbenika nekaj samoumevnega, da poskuša razumeti in izvajati gregorijanski koral tak, kot je bil skomponiran?” Gl. CARDINE, EugÈnE, La Sémiologie Grégorienne, prevedeno po prvi objavi besedila v delu GöschL, JoHANnes B., Semiologische Untersuchungen zum Phänomen der Gregorianischen Liqueszenz, I, Dunaj 1980, str. I.

${ }_{4}$ Osrednji tok glasbenozgodovinopisnega razpravljanja o glasbenem interpretiranju je razviden $\mathrm{v}$ tridesetih letnikih revije Early Music. 
predstave o glasbenem delu. Nadalje se psihologija ukvarja $z$ vprašanji vizualnega in korelacije tega $\mathrm{z}$ izraznimi funkcijami posamičnih delov interpretirane kompozicije itd. ${ }^{5}$ Poleg zgodovinopisno in psihološko usmerjenih raziskav pa je glasbeno interpretiranje tudi predmet glasbenoestetskega in glasbenofilozofskega razpravljanja. Kaj je interpretacija $v$ razmerju do glasbenega dela, kaj je njegov smisel, so v prvi vrsti glasbenoestetska vprašanja, saj se jim je mogoče približati le $z$ miselnim aparatom, ki se je izoblikoval $v$ okviru tradicije filozofskoestetskega razpravljanja o glasbi. Kot si je mogoče predstavljati, se glasbenoestetsko razpravljanje o interpretiranju pogosto navezuje na glasbenozgodovinopisne raziskave, zastavljajoč si vprašanje o njihovem smislu.

Pričujoči spis želi uvesti v probleme teoretičnega razmišljanja o glasbenem interpretiranju, ki sodi z ozirom na pojmovni svet, ki se ga poslužuje, v področje glasbene estetike in filozofije glasbe. V tem smislu so v njegovem osrednjem delu podana in komentirana razmišljanja in izpeljave nekaterih izbranih razprav, objavljenih $\mathrm{v}$ zadnjih dveh desetletjih, ki se na teoretični način soočajo $z$ vprašanji glasbenega interpretiranja, zlasti $z$ vprašanjem njegove možne ali nemožne zgodovinske avtentičnosti. V miselnem ozadju razpravljanja o glasbenem interpretiranju pa so v zadnjem delu spisa nadalje razvite in med sabo povezane nekatere misli in izpeljave, predstavljene v njegovem drugem delu. Kratko je vsebino zadnjega dela spisa mogoče izraziti v obliki treh tez: 1 . Glasba se v tem, da je interpretativna umetnost, v bistvu ne loči od drugih umetnosti. 2. Rekonstrukcija zgodovinsko avtentične zvočnosti sama po sebi ne vključuje glasbenega smisla. 3 . Interpretacije so po svoji bitnosti intencionalna dejanja.

\section{Pogledi}

Med drugimi se je $z$ vprašanjem razmerja med glasbenim delom in njegovimi izvedbami ukvarjal tudi Thomas Carson Mark, ki ga je zaradi večje preglednosti skrčil na področje klavirskih interpretacij. V uvodnem delu razprave o "filozofiji" klavirske igre ${ }^{6}$ se Mark v smislu analitičnega filozofiranja najprej poigrava $z$ razmerji med osnovnimi pojmi svojih razmislekov, opozarjajoč na izmuzljivost pojma glasbenega dela in uvajajoč osrednje vprašanje svoje razprave, vprašanje o tem, kaj so interpretacije. Glasbeno delo je po Marku nekaj takega, kar ima lahko neskončno veliko dejanskih, prek čutov dostopnih uresničitev, izvedb, instanc. Vendar pa glasbenega dela ni mogoče zvesti na instance, kar bi pomenilo, da je glasbeno delo le vrsta lastnih instanc. Če bi bilo tako, bi se o Schubertovi Deveti simfoniji lahko govorilo šele od leta 1844 dalje, ko je bila prvič izvedena. Po Marku tudi partitura ni jamstvo obstoja glasbenega dela, saj si je mogoče misliti improvizirano, nenapisano sonato, ki more biti glasbeno delo tudi brez glasbenega zapisa. Nadalje Mark uvede razločevanje med instanco dela in njegovo interpretacijo: instanca je le uzvočitev tistega, kar je zapisano v partituri, interpretacija pa nujno dejanje, nekaj, kar nekdo v trenutku izvajanja stori. ${ }^{7}$ Chopinova etuda, uresničena na mehanični način, npr. $z$ valjem $z$ ustreznimi žebljički, ki bi, vstavljen v klavir, proizvedel v Chopinovem zapisu določene tone, ne bi bila njena izvedba, bila pa bi njena instanca. Zdelo bi se, da so izvedbe in instance, ki jih torej ni mogoče enačiti z glasbenim delom, potrebne zato, da je glasbena dela mogoče spoznati; da ni tako, je razvidno iz dejstva, da je glasbe-

\footnotetext{
5 "Psychology of music", The New Grove, 20, London 22001, str. 546-548.

6 Mark, Thomas Carson, "Philosophy of Piano Playing: Reflections on the Concept of Performance", Philosophy and Phenomenological Research, XII, 1980, str. 299-324.

7 Na podoben način, le da izhaja iz glasbenega življenja, prakse, ločuje izvajalce od interpretov tudi Stravinski: STRAVINSKI, IGOR, Glasbena poetika, prev. MARIJA BERGAMO, Ljubljana 1997, str. 84.
} 
na dela možno tudi tiho brati, tako kot literarna besedila. Ob tem Mark pripominja, da z ozirom na to, kako umetniško delo dejansko živi, razlika med glasbo in literaturo ni tako velika, kot se navadno misli. Vendar pa zahteva branje glasbenega dela določeno $z$ izkušnjo pridobljeno znanje, saj je pri branju glasbenega zapisa treba vedeti, kako se zapisano sliši, to pa predpostavlja izkušnje s toni. Brati je torej mogoče le zato, ker tisti, ki to more, iz realne izkušnje z zvokom ve, kako kaj zveni. To pa pomeni: čeprav je glasbeno delo mogoče spoznati brez instance in brez izvedbe, ni mogoče, da bi vsa glasbena dela obstajala brez izvedb, se pravi, da bi glasba obstajala brez dejanskega zvoka in izkušenj z njim. A ker velika večina ljudi ne bere partitur, se smisel izvajanja in interpretiranja vendarle kaže $v$ tem, da se prek interpretacij, instanc spoznavajo glasbena dela. V nadaljevanju Mark skuša dokazati, da ni tako.

Pri reševanju problema, kaj so interpretacije in čemu služijo, se Mark poslužuje analogije $s$ področja govora, in sicer analogije $s$ citatom (quotation), ki je na prvi pogled nekaj primerljivega instanci ali interpretaciji glasbenega dela. Citat mora po Marku izpoljnjevati tri pogoje, da bi ga bilo mogoče imeti za citat: vsebovati mora iste besede kot citirana izjava sama, narejena $v$ preteklosti; vsebovati jih mora hote, saj izjava, ki slučajno sovpada $z$ neko preteklo izjavo, ni citat; slednjič mora biti tudi citiranje samo namerno citiranje. (Razloček med drugim in tretjim pogojem iz Markovega pisanja ni povsem razviden.) Ti trije pogoji imajo vzporedje v glasbeni izvedbi: izvedba mora vsebovati tisto, kar je $\mathrm{v}$ glasbenem zapisu in to mora vsebovati hote, saj zaigrana ali zapeta melodija, ki bi slučajno sovpadala $\mathrm{z}$ nekim glasbenim zapisom, ni njegova izvedba; slednjič mora biti izvedba hoteno igranje izbrane kompozicije. Vendar pa samo glasbeno citiranje po Marku še ni interpretiranje. Da bi dognal, kaj je interpretacija (performance), se Mark vpraša po razliki med citiranjem in izjavljanjem, zatrjevanjem (asserting). Za zatrjevanje, izjavljanje je mogoče uporabiti že izrečene besede in ob zavesti, da so bile že izrečene, $z$ njihovim citiranjem torej, je zatrjevanje hkrati tudi citat. Isto je mogoče povedati v obratni smeri: Citat sam po sebi govorno ni dejaven; obrnjen je nazaj, v trenutek, ko so bile citirane besede prvič izrečene ali zapisane. Če pa je citat izrečen kot zatrdilo, kot nova, v trenutku izreka veljavna izjava, je govorni akt, $s$ katerim govorec, kljub temu, da zavestno citira, nekaj pove. Pri tem je bistven govorčev namen: zatrdilo, četudi je citat, je zatrdilo le, če govorec hoče, da je razumljeno kot zatrdilo in če ga poslušalec sprejme kot zatrdilo, četudi ga prepozna kot citat. $Z$ ozirom na to, da nastopi citat kot izjava $\mathrm{v}$ novi govorni situaciji, ni težko razumeti, da lahko dobi nov pomen, različen od tistega, ki so ga imele iste besede $v$ trenutku, ko so bile izrečene ali zapisane prvič.

Vse to je mogoče prenesti na glasbeno interpretiranje: Izvajano glasbeno delo je citat; a da bi bila njegova izvedba interpretacija, mora biti tudi izjava tistega, ki ga izvaja. Pri tem je pomemben namen: interpret mora hoteti, da je njegovo izvajanje razumljeno kot zatrdilo in poslušalec mora verjeti, da posluša zatrjevanje. Kot skuša govorec s svojo izjavo, ki je lahko citat, izzvati v poslušalcu prepričanje, da stvari so tako, kot zatrjuje, celo v primeru, da tega sam ne verjame, tako skuša postopati tudi glasbeni interpret. Interpretacija mora biti takšna, da poslušalec lahko reče: "Tako je. Tako stvari glasbeno so." Interpretacija je torej citat, ki je hkrati trditev, izjava z določenim namenom, in taka lahko privzame $\mathrm{v}$ trenutku svojega udejanjenja nove pomene.

$\mathrm{V}$ nadaljevanju se Mark osredotoči na namernost, intenco kot bistveno lastnost glasbene interpretacije, $s$ katero je mogoče razložiti dejstvo, da morejo biti interpretacije danega glasbenega dela različne. Zopet si pomaga $z$ govorno analogijo. Pri zatrjevanju je zatrjevalec prepričan, da je tisto, kar zatrjuje, res in s svojim zatrdilom hoče napraviti določeni učinek. Če le mehanično ponavljam določeno besedilo - npr. otroško pesmico, ki uči, koliko dni je v katerem mesecu, da bi se osvestil, da jih ima avgust enaintride- 
set - ponavljanje kot govorni akt ni zatrjevanje, čeprav je vse, o čemer pesmica govori, res. Podobno je pri glasbeni izvedbi: samo mehanično igranje brez namernosti ni interpretiranje. Prav intenca pomaga razumeti spolzki koncept interpretacije. $Z$ intenco, namero izgovorjene besede morajo imeti smisel. Ta smisel ni razlaga citiranih besed, ni sodba o originalni izjavi, ni pogled na citirane besede od zunaj. Ta smisel je tisto, kar govorec $\mathrm{v}$ izgovorjenih in citiranih besedah $\mathrm{v}$ trenutku govornega akta vidi sam in kar želi z njimi reči. Glasbena analogija intencionalnega citiranja je interpretacija $z$ lastnim glasbenim smislom in lastno namero. Glasbena interpretacija mora imeti smisel, ki ga interpret sam sprevidi, najde $\mathrm{v}$ interpretiranem delu in ki ga $\mathrm{z}$ namenom prepričati druge poda $v$ interpretativnem aktu. Interpret Brahmsa ne pove svojega mnenja o Brahmsovi skladbi, pač pa poda tisto, kar čuti in verjame, da je imel Brahms v mislih. Ob tem ni nujno, da je glasbeni smisel interpretacije isti kot smisel, ki ga je $\mathrm{v}$ svojem delu videl skladatelj in prav tako ni nujno, da najdejo različni interpreti v istem glasbenem delu isti pomen. S tem pa je mogoče razložiti, zakaj so si interpretacije različne. Markovo razpravljanje se izteče v ugotovitev, da sta glasbeno delo, kompozicija in njena interpretacija dvoje umetniških del, povezanih na mnogoobrazen in zapleten način. ${ }^{8}$

Mark se ne sprašuje niti o historično avtentičnem niti o tem, zakaj natančneje so si interpretacije različne. Tem vprašanjem se je posvetil Gary Tomlinson, ki je izdelal teorijo, s katero je mogoče razložiti, zakaj so si interpretacije istega glasbenega dela nujno različne in odkod prihaja tisto, zaradi česar se ločijo. ${ }^{9}$ Iskanje zgodovinsko avtentične interpretacije danega glasbenega dela je po Tomlinsonu upravičeno le, če verjamemo, da se s tem približamo avtentičnemu pomenu. Vendar pa avtentični pomen, kot opozarja Tomlinson, ne more biti tisto, kar so v dano glasbeno delo položili njegovi ustvarjalci ali zgodovinska publika; z ozirom na zgodovinsko razdaljo more biti le to, kar si sodobni poustvarjalci mislijo ali verjamejo, da je njegov avtentični pomen. To pa je lahko vedno nekaj drugega. Teoretično Tomlinson razloži možnost različnih interpretacij z osnovnimi postavkami klasične semiotike, ki je obvladovala in še obvladuje velik del humanistične tradicije $\mathrm{v}$ zadnjem stoletju: Posamični znak sam zase nima nobenega pomena. Pomene dobijo znaki šele $v$ igri medsebojnih odnosov: $z$ medsebojnimi odnosi znakov nastane kontekst in posamični znaki morejo dobiti določeni pomen šele znotraj svojega konteksta. Pomen znaka je tako nujno le kontekstualni pomen in prav zato se $s$ širjenjem, bogatenjem konteksta - vsega tistega, v čemer dani znak dejansko obstoji - poglabljajo, izostrujejo ali spreminjajo tudi pomeni posamičnih znakov. Akt osmišljanja ali opomenjenja je torej recipročni, obojestranski proces: hkrati ko znak dobi pomen iz konteksta, $v$ katerem se pojavi, kontekst tudi razširi in spremeni. ${ }^{10}$

$\mathrm{V}$ smislu prikazanih postavk se Tomlinsonu ukvarjanje z zgodovino kaže kot neke vrste pogovor med zgodovinarjem in preteklostjo. Zgodovinar raziskuje, spoznava, rekonstruira pretekle kontekste, ki pa jih nujno razumeva le tako, da jih sprejme v svoj lastni kontekst. Razumevanje znaka iz preteklosti je njegova prilagoditev tistemu, kar v zgodovinarju že je. Objektivnosti ni. Tomlinson pravi, da je delo zgodovinarja v določenem smislu podobno delu kulturnega antropologa. Tudi ta si prizadeva vzpostaviti pogovor med različnimi sočasno obstoječimi konteksti, in sicer v prepričanju, da je cilj in smisel kulturne antropologije širjenje človeškega diskurza sploh. ${ }^{11}$ Zgodovinar širi diskurz v časovno globino, pri čemer so pomeni znotraj preteklih kontekstov tisto, kar si

8 V zadnjem delu razprave Mark razmišlja še o pomenu virtuoznosti.

9 Tomurnson, Gary, "The Historian, the Performer, and Authentic Meaning in Music", Authenticity and Early Music, ur. NicHoLAS KeNYON, Oxford 1988, str. 115-136.

${ }^{10}$ Nav. delo, str. 118 .

${ }^{11}$ Tomlinson se sklicuje na Clifford Geertza; nav. delo, str. 119 
predstavlja, da bi mogli biti. Pomen znaka iz preteklosti zaživi šele v kontekstu, ki ga zgodovinar zanj rekonstruira; a ta kontekst je hkrati nujno del zgodovinarjevega lastnega konteksta, ki postaja ob dialogu s preteklostjo večji in bogatejši. Iz tega sledi, da je pomen, smisel danega glasbenega dela iz preteklosti, kot si ga lahko predstavljamo, po eni strani $v$ njem samem, $v$ obsegu od njegovega prvega do njegovega zadnjega tona, po drugi strani pa $v$ vsem tistem, kar glasbeno delo obkroža. Toni sami kot znaki nimajo pomena in smisla razen $\mathrm{v}$ kontekstu celotne kompozicije. A tudi celotno kompozicijo je na višji ravni mogoče razumeti kot znak, ki ima svoj smisel v širšem kontekstu, ki si ga lahko zamišljamo kot glasbenozgodovinsko okolje, v katerem je delo nastalo. Kompoziciji kot celoti daje smisel šele ta. A slednjič je rekonstruirani glasbenozgodovinski kontekst tisto, kar si zamišljamo, da bi lahko bil, saj je nujno le razpršina v kontekstu, ki ga nosi v sebi zgodovinar oz. interpret.

$S$ to izpeljavo je Tomlinson po eni strani opravičil vsakršno zgodovinsko raziskovanje in študij zgodovinsko avtentičnega glasbenega interpretiranja, po drugi strani pa rešil svobodo interpreta. Sodobni interpret lahko spoznava pretekle kontekste. Lahko si zamišlja smisle interpretiranega dela, ki so tudi v njegovem zgodovinskem okolju mogli biti različni, saj si ni težko predstavljati, da skladateljev kontekst ni bil nujno isti kot kontekst njegovega interpreta, in da je bil ta zopet lahko nekaj drugega kot kontekst zgodovinske publike. A hkrati so pretekli konteksti, kot si jih interpret more zamišljati, tudi del njegovega lastnega: so le tisto, kar si misli, da so bili. Interpret vzpostavlja tako dialog s preteklostjo, hkrati pa ostaja on sam.

Vzorčni primer rekonstruiranja preteklega konteksta, ki ga Tomlinson podaja v nadaljevanju, se ne nanaša na glasbeno interpretiranje, pač pa na miselno okolje, v katerem je nastal "Orfeo", glasbenogledališka predstava Angela Poliziana, igrana oz. peta leta 1480 v Mantovi. Glasba predstave ni ohranjena in morda je bila zgolj improvizirana v smislu sočasnih glasbenih formul za improvizirano petje posamičnih pesniških oblik. Vlogo Orfeja je $\mathrm{v}$ predstavi pel Baccio Ugolini, dober znanec humanista in filozofa Marsilia Ficina, prevajalca in komentatorja Platona in antičnih novoplatonističnih filozofov. Ficino si je kot poznavalec antične filozofije ustvaril obsežno kozmološko platonističnomagično vizijo stvarstva, v kateri je imela svoje mesto tudi glasba. $\mathrm{V}$ duhu novoplatonistične filozofije je glasbi pripisal moč, po kateri naj bi človeka dvigala k višjemu, k nebeški lepoti, kot si jo je zamišljala novoplatonistična filozofija; hkrati ji je pripisal tudi magično zdravilno moč in znano je, da je $v$ tem smislu sam prakticiral petje ob spremljavi lire da braccio. Zdi se, da je pel antične grške himnuse, za katere je doba verjela, da so Orfejevi. Ves ta miselni kontekst je bil gotovo znan Ugoliniju in zelo verjetno je na predstavi leta 1480 razumel sebe kot pevca, katerega petje naj bi imelo v smislu Ficinijeve vizije posebno magično in odrešilno moč.

Tomlinson se je s študijo izbranega primera, "case study" in njej sledečim zaključkom odmaknil od glasbenega interpretiranja v osnovnem pomenu izraza. Svoje razpravljanje namreč zaključuje $\mathrm{z}$ mislijo, da je smisle glasbe treba iskati zunaj glasbenih del samih; iskati jih je treba $v$ tistih diskurzih, iz katerih so izšla. Vendar je njegov teoretični model mogoče aplicirati tudi na glasbeno interpretiranje samo: historično "avtentična" glasbena interpretacija bi, sledeč Tomlinsonu, mogla podati tisti glasbeni smisel, ki ga sodobni interpret najde ob tem, ko si zamišlja interpretacijo, kakršna naj bi obstajala v zgodovinskem okolju, v katerem je delo nastalo.

Tomlinson se očitno zaveda, da ni zgodovinske objektivnosti, na področju glasbene interpretacije pa ne historične avtentičnosti. Glasbeno delo oz. njegov pomen sta zanj nekaj, kar je treba vedno znova določiti oz. najti. Prav nasprotne možnosti pa išče platonistično usmerjeno glasbeno filozofiranje. Sam glasbeni platonizem, kakršen obstoji v 
glasbenofilozofski misli zadnjih desetletij, nikakor ni nadaljevanje antične platonistične teorije glasbenega etosa, ki je $\mathrm{v}$ različnih oblikah obstajala tudi $\mathrm{v}$ misli novodobnih stoletij, med drugim tudi kot teorija afektov. Bolj kot to je razmišljanje o bitnosti glasbenih del, utemeljeno na platonistični metafiziki oz. izpeljano iz pojmov, s katerimi je Platon razlagal razmerje med svetom idej in čutno zaznavnimi predmeti realnega sveta. Zdi se, da je temeljna značilnost platonističnega razpravljanja o glasbi prepričanje, da glasbenega dela ni mogoče zvesti na vrsto izvedb in množico kopij njegovega glasbenega zapisa; glasbeno delo naj bi bilo prisotno in določeno $\mathrm{z}$ nečim drugim in kopije partitur in izvedbe naj bi bile le njegove instance. A če glasbeno delo ni niti $v$ izvedbah niti v partiturah, se zastavljajo nadaljnja vprašanja: kje obstoji in kako, kaj je njegova bitnost, kaj njegova identiteta, kdaj in kako nastane, če je sploh mogoče govoriti o njegovem nastanku itd. Kot je mogoče pričakovati, dajejo razpravljalci na ta vprašanja različne odgovore. ${ }^{12}$

Kot je bilo omenjeno, vključuje platonistično razmišljanje o glasbi tudi razpravljanje o razmerju med glasbenim delom in njegovimi interpretacijami. $S$ tem vprašanjem se je ukvarjal tudi Peter Kivy, in sicer v vrsti esejev, zasnovanih kot polemični odgovori drugim razpravljalcem. ${ }^{13}$ Prav zaradi takšne oblike je Kivyjevo gledanje na odnos med glasbenim delom in njegovimi interpretacijami treba izluščiti in sestaviti iz vrste obravnav ožje zamejenih vprašanj. Iz Kivyjevega pisanja je razvidno, da je prepričan, da glasbena dela obstojijo, da so samostojne bitnosti in da imajo svojo identiteto: tisto, zaradi česar so, kar so, in s čimer so določena. Takšno pojmovanje je izraženo zlasti v njegovem eseju o izvajalski zvestobi hotenju ne več živečih skladateljev. ${ }^{14}$ Zdi se, da si Kivy predstavlja, da so glassbena dela, bolj kot da bi bila ustvarjena, na neki način odkrita in da so skladatelji, bolj kot da bi bili njihovi ustvarjalci, njihovi odkritelji. Kot poudarja, je razmerje med izumom in odkritjem $v$ filozofiji znanosti zapleteno, saj izum navadno vključuje tudi odkritje, se pravi sprevid nečesa, kar je bilo že poprej, le da tega še nihče ni opazil. Tudi v glasbi je mogoče govoriti o odkritjih: Tristanov akord je za Kivyja gotovo odkritje, saj je njegovo bistvo - če ga skušamo imenovati z drugimi besedami kot Kivy - v sprevidu drugačne notranje konstelacije tonov tudi pred sredino 19. stol. znanega akorda. Ker pa je Tristanov akord možen le $v$ glasbenem jeziku določenega Wagnerjevega dela, je tudi to delo mogoče videti kot odkritje. ${ }^{15}$ A čeprav Kivy dopušča možnost, da so glasbena dela odkrita, se ne spušča $v$ metafiziko njihovega modusa bivanja pred njihovim skladateljskim odkritjem.

Kivy v svojem pisanju ne pove, kaj glasbeno delo je, pač pa govori o tem, s čim je določeno. Pogled na to vprašanje je izčistil v obliki odziva na pisanje sicer tudi platonistično usmerjenega Jerrolda Levinsona, ki pojmuje kot konstitutivni del identitete glasbenega dela tudi njegovo instrumentacijo. ${ }^{16} \mathrm{Kivy}$ je nasprotno prepričan, da je identiteta glasbenega dela le $\mathrm{v}$ njegovi tonski strukturi: $\mathrm{v}$ samih tonih in njihovih medsebojnih odnosih. Glasbeno delo ne izgubi svoje identitete, če ga transponiramo, niti je ne izgubi, če ga orkestriramo ali prenesemo na drugi instrument ali ansambel. Bachova fuga je vedno to, kar je, najsi je igrana na enem od glasbil s tipkami, za kakršno je bila napisana, ali pa jo igra pihalni trio. Posebno ekspresivna mesta $v$ glasbenih delih, poverjena dolo-

\footnotetext{
12 Vzorčni primer platonističnega koncepta glasbenega dela, kot si ga je zamislil Jerrold Levinson, je podan v delu: GoeHR; LYDIA, The Imaginary Museum of Musical Works, Oxford 1992, str. 44-68.

${ }^{13}$ KIVY, PETER, The Fine Art of Repetition, Cambridge 1993, str. 33-133 (poglavje "Work and performance"). Kivy je kasneje posvetil celotno monografijo vprašanju glasbenega interpretiranja: Authenticities: Philosophical Reflections on Musical Performances, Ithaca 1995. Njena vsebina tu ni upoštevana.

14 "Live performances and dead composers: On the ethics of musical interpretation", nav. delo, str. 95-116.

15 "Platonism in music: A kind of defense", nav. delo, str. 38-46.

16 "Orchestrating Platonism", nav. delo, str. 75-94.
} 
čenemu glasbilu, za katera bi se zdelo, da imajo svojo izraznost prav v izbiri določenega instrumenta, so po Kivyjevem mnenju ekspresivna, tudi če niso igrana s predvidenim instrumentom; njihova ekspresivnost je $\mathrm{v}$ tonski strukturi sami in izbrani instrument jo le podčrtava oz. se je zdel skladatelju $z$ ozirom na naravo ekspresivnosti najprimernejši. Tako je mogoče reči, da je dana kompozicija slabo instrumentirana, da je igrana na neprimernih glasbilih, da je slabo izvedena, da je njena transpozicija neustrezna; nikakor pa ni mogoče reči, da bi bila $z$ vsemi temi spremembami zanikana njena istovetnost. Še vedno je ista Bachova fuga. Identiteta kompozicije je torej v tonski strukturi sami, določeni in fiksirani z glasbenim zapisom, ki lahko vsebuje tudi druga določila, čeprav za identiteto kompozicije niso bistvena (izbira instrumentov, dinamika, tempo, agogika itd.).

Iz prikazanega je že mogoče videti platonistične obrise Kivyjevega razmišljanja: Glasbena dela so skladateljska odkritja, določena s tonsko strukturo in fiksirana v partiturah. Kot odkritja so v bistvu neodvisna od glasbenega zapisa, ki je le način njihove objave, način, prek katerega so dostopna. Izgubljena ali nikoli napisana kompozicija sicer ni izvedljiva, a kljub temu si je mogoče predstavljati, da obstoji kot ideja (v platonističnem smislu). Ob vsem tem je razumljivo, da Kivy pojmuje glasbene interpretacije kot nekaj, kar je $\mathrm{v}$ podrejenem odnosu do glasbenega dela kot ideje in njegovega pomena. Kot pravi sam, so interpretacije $\mathrm{v}$ odnosu do glasbenega dela kot primerki, v fizičnem svetu obstoječe množice istovrstnih stvari v odnosu do ideje. ${ }^{17}$ Interpret torej ne more drugače, kot da prek glasbenega zapisa uresniči in udejani pomen glasbenega dela; a katera koli interpretacija je le ena od njegovih instanc.

Prav zaradi takšnega razumevanja glasbenega dela je Kivy problematiziral historično avtentično interpretiranje,$^{18}$ saj je prišel do spoznanja, da ni združljivo s tistim interpretiranjem, ki izhaja iz iskanja pomena glasbenega dela samega. Na prvi in površinski pogled bi se sicer zdelo, da je zgodovinska avtentičnost varuh identitete glasbenega dela, saj upošteva zvočni in izvajalski kontekst, vendar po Kivyju ni tako. Zgodovinska avtentičnost je $\mathrm{v}$ rekonstruiranju $\mathrm{v}$ preteklosti dejansko zvenečega; tako naj bi bila npr. verna obnovitev tistega, kar so leipziški meščani slišali leta 1727 , ko je Bach izvedel svoj Matejev pasijon. Vendar: Bach je imel lastno predstavo o svojem delu in gotovo je imel ob njegovi izvedbi določeni interpretativni namen. Ali je leipziška praizvedba ta namen dosegla? Ali je bila najboljša možna, ali je bila brez napak; ali je ustrezala tistemu, kar je Bach dejansko hotel? Na ta vprašanja ni mogoče odgovoriti pritrdilno, kar pomeni: tisto, kar se je dejansko slišalo v Leipzigu ali kjer koli, ne more veljati za sodobno izvajalsko normo. Vendar je problem po Kivyju še globlji: Bachovo glasbo je danes mogoče slišati kot anticipiranje tistega, kar so naredila kasnejša obdobja, a ljudje iz prve polovice 18. stol. je niso mogli slišati tako. To pomeni: tudi če se natančno rekonstruirajo stare interpretacije, glasbe še vedno ni mogoče dojeti na tisti način, kot so jo njeni sodobniki. Če pa bi Bachovo glasbo že mogli slišati z ušesi ljudi izpred tristotih let, bi se lahko zgodilo, da bi bili do nje morda celo brezbrižni, tako kot so bili leipziški meščani.

Historična avtentičnost je po Kivyju problematična še v nečem drugem. Izvedba danega dela iz preteklosti se sicer more bolj ali manj približati tistemu, kar je $v$ zgodovini $v$ resnici zvenelo, pač v odvisnosti od stopnje glasboslovnega vedenja, in tako si je mogoče zamisliti interpretacijo Matejevega pasijona, ki bi bila bolj ali manj blizu Bachovi. Vendar pa historično avtentična izvedba, ki je predvsem rekonstrukcija na zgodovinopisnem znanju zamišljene prvotne izvedbe, po Kivyju v nečem ne more biti avtentična:

17 “... that works are universals, or types, or kinds, performances related to them as particulars, tokens, or instances." Nav. delo, str. 75 .

${ }^{18} \mathrm{KIVY}$, PeTER, The Fine Art of Repetition, str. 117-133 ("The 'historically authentic' performance"). 
Ko je Bach izvajal Matejev pasijon, gotovo ni "rekonstruiral izvedbe 18. stol.", pač pa je ustvarjal njegovo interpretacijo. Ob tem ni slepo sledil določenim normam, ki jim mora slediti rekonstrukcijska izvedba, prej jih je kršil. Njegova interpretacija je gotovo stremela k muzikalnosti, prepričljivosti, gotovo je bila živa in interpretativno domiselna. Vse te lastnosti pa historično avtentične interpretacije včasih tudi pogrešajo, saj težijo k nečemu drugemu. Rekonstrukcijske izvedbe se morajo pogosto odpovedovati prosti in neomeje$\mathrm{ni}$ interpretativni umetniški fantaziji in $\mathrm{v}$ tem pogledu gotovo niso primerljive $s$ tistimi, $\mathrm{ki}$ so v zgodovini dejansko zvenele. Interpretiranje, ki sledi glasbenemu delu in njegovemu pomenu samemu, se po Kivyjevem mnenju ne more omejevati na rekonstruiranje starih izvedb. ${ }^{19}$

\section{Interpretacija kot intencionalno dejanje}

Ko Thomas Carson Mark vzporeja glasno in tiho branje besedila $\mathrm{z}$ igranjem glasbenih del in njihovim branjem, izrazi prepričanje, da med glasbo in literaturo z ozirom na način njunega pojavljanja ni tako velike razlike, kot se navadno misli. Markovo misel je mogoče razvijati dalje. Literarno delo, roman se more brati povsem prosto: vsakdo lahko samosvoje doživlja prikazani splet dogodkov in usod z ozirom na lastna doživetja in izkušnje, kar pomeni, da ga lahko interpretira po svoje. Tudi ob likovnem delu je opazovalec prost. Vidi ga, kot ga more ali kot ga hoče videti, pri čemer lahko vzpostavlja proste povezave: na isti sliki se lahko osredotoči enkrat na usklajevanje barv, drugič na kompozicijo figur, tretjič na način prenosa resničnosti v slikarsko iluzijo itd. Enako je $z$ glasbo. Tudi glasbeno delo je mogoče prosto brati ali igrati, ga razumevati in interpretirati na različne načine: na danem mestu kompozicije je mogoče izslišati in izpostaviti sicer zakrito melodično linijo ali pa jo pustiti v ozadju; le z malenkostno nepredpisano dinamično nianso je mogoče ustvariti vtis, kot da se je nepričakovano odprlo novo obzorje, a tak postopek je mogoče tudi izpustiti; $z$ doživetim akcentuiranjem, četudi ni predpisano, je mogoče vzpostavljati nove, tudi nenavadne povezave med posamičnimi sintaktičnimi deli kompozicije, kot je mogoče to tudi opustiti; rahla dinamična izpostavitev tona, za katero ni nujno, da bi bila označena $v$ partituri, spremeni barvni spekter sozvočja in da kompoziciji drugačen odtenek itd. itd. V tem, da je interpretativna umetnost, se glasba $\mathrm{v}$ jedru ne razločuje od drugih umetnosti; od drugih umetnosti se loči le v načinu, kako je v dejanskem življenju prisotna. Ob branju literarnega dela (če ni uprizoritev drame) je vsak bralec tudi svoj lastni interpret, $v$ glasbenem življenju pa je interpretacija zaupana poklicnim interpretom, ki svoje interpretacije, kar pomeni svoja razumevanja in slišanja, posredujejo drugim. A če si zamislimo, da lahko ustrezno izurjeni sam bere glasbeni zapis, ob čemer si ga nujno tudi interpretira, je njegovo branje povsem primerljivo $s$ prostim branjem literarnega dela.

Zahteva, da je v literarnem delu nekaj treba razumeti na določeni način in ne drugače, je lahko tudi krnjenje bralčeve proste umetniške fantazije. Če se glasbeni interpret sme primerjati s svobodnim bralcem, bi moral biti ob svojem podoživljanju glasbenega dela enako prost. To bi pomenilo, da bi se $\mathrm{v}$ interpretativnem aktu ravnal po svoji predstavi in svojem hotenju. A tako gledanje je, vsaj na površini, v nasprotju z zahtevami zgodovinsko avtentičnega interpretiranja.

\footnotetext{
${ }^{19} \mathrm{Na}$ podoben način je težnjo po historični avtentičnosti zavrnil tudi R. Scruton: Dokler je glasba preteklosti del določene kulture, kot je npr. Bachova glasba del današnje, je nujno tudi izhodišče različnih interpretacij. Šele izguba stika $z$ njo privede do dvoma o tem, kako bi jo bilo treba izvajati, in do iskanja odgovora v rekonstruiranju starih izvedb. ScRuToN, Roger, The Aesthetics of Music, Oxford 1997, str. 447-450.
} 
Ob nekaterih historično avtentičnih interpretacijah se vzbuja vtis, da so bolj kot interpretacije glasbenih del poskusi rekonstruiranja glasbenih dogodkov preteklosti. Zdi se, da si ne zastavljajo vprašanja, kako interpretirati glasbeno delo, npr. Matejev pasijon, srednjeveško liturgično dramo, pač pa, kako čim bolj verno rekonstruirati izvedbo iz časa, v katerem je delo nastalo, se pravi, kako čim bolj verno rekonstruirati pretekli glasbeni dogodek, npr. srednjeveško uprizoritev liturgične drame. Koncert s tako izvedbo postavlja sodobno publiko predvsem $\mathrm{v}$ vlogo opazovalca uprizoritve obnovljenega koncerta iz preteklosti in šele v drugi vrsti ji omogoča, da spremlja interpretirano delo samo, včasih pa ji s tem, ko se osredotoča na obnovitev glasbenega dogodka, poslušanje kompozicije celo otežkoča.

Gotovo si v današnjem glasbenem življenju ni mogoče predstavljati interpretiranja glasbe, zlasti tiste izpred sredine 18. stol., brez glasbenozgodovinopisnega vedenja o tem, kakšni so bili zvočni in izvajalski konteksti njenih zapisov. Vendar je treba pritrditi Tomlinsonu in Kivyju: iskanje historično avtentičnega interpretiranja je utemeljeno le, če je hkrati tudi odkrivanje glasbenega smisla. Kaj je ta smisel, je pri tem drugo vprašanje. Interpretacija kompozicije mora torej sprevideti njen smisel; a odkrivanje njenega smisla ni isto kot odkrivanje historično avtentične zvočnosti in rekonstruiranje nekdanjih izvedb. Čeprav sta iskanje zgodovinsko avtentičnega igranja in iskanje glasbenega smisla v dejanskem glasbenem življenju prepleteni in sočasno potekajoči dejavnosti, si nista enakovredni. Iskanje glasbenega smisla lahko privede do zgodovinsko avtentične interpretacije, in obratno: tudi študij zvočnega in izvajalskega konteksta lahko privede do glasbenega smisla igrane kompozicije. A rekonstrukcije zgodovinskih izvedb same po sebi še niso jamstvo glasbene smiselnosti.

Interpretacija je, kot poudarja Mark, dejanje: nekaj, kar nekdo naredi, in sicer z določenim namenom. V dejanskem glasbenem življenju so interpretacije sicer največkrat pripravljene vnaprej: pianist vadi in izdela interpretacijo, ki vključuje določeno agogiko, dinamiko itd., dirigent jo pripravi na vajah $\mathrm{z}$ orkestrom in predstavi na koncertu. Tako pripravljena interpretacija je lahko mnogokrat izvedena, ponovljena, posneta pa je $\mathrm{v}$ povsem enaki obliki dostopna kadar koli. Vendar se je pri teoretičnem razpravljanju o glasbenem interpretiranju treba osredotočiti na bistveno in odmisliti pri tem vse kontingentno. Če odmislimo torej nebistvene lastnosti dejanskega glasbenega življenja: dejstvo, da interpretacije nastajajo $\mathrm{z}$ ustreznimi pripravami in da se morejo ponavljati, se interpretacije kažejo kot enkratna in nepredvidljiva dejanja. Čeprav je pianist interpretacijo pripravil vnaprej, je njegovo igranje - kot dejanje $z$ določenim hotenjem, ki se izpolnjuje v čisto določenih okoliščinah; kot namerni, intencionalni akt s hotenim učinkom nekaj, kar je odvisno od trenutka igranja, saj se v umetniškem zanosu pianist lahko tudi oddalji od gole predstavitve tistega, kar je pripravil. $S$ tem je njegovo igranje $v$ jedru nepredvidljivo in $\mathrm{v}$ jedru tudi neponovljivo, saj se ob naslednji izvedbi, tudi če je zelo podobna prejšnji, lahko prepusti drugačnemu navdihu. Vsekakor je naslednja izvedba, četudi je zgolj ponovitev prejšnje, nujno drugo interpretativno dejanje. A ne le, da interpretacije kot intencionalna dejanja niso predvidljive; tudi obnoviti in rekonstruirati jih ni mogoče. Vse, kar od dane interpretacije ostane, je strogo vzeto le spomin ali pa vtis, učinek, ki ga je imela na poslušalce. Tudi če se kdo vzoruje pri preteklih interpretacijah in jih kopira, je njegova domnevno obnovljena interpretacija novo interpretacijsko dejanje $z$ lastnim hotenjem.

Tako gledanje vzpostavlja drugačen odnos med skladateljem in interpretom, oz. med glasbenim delom in njegovimi interpretacijami. Če je interpretacija dejanje z lastnim hotenjem, je v nekem sicer težko določljivem smislu neodvisna od glasbenega dela, čeprav je to še tako natančno določeno z glasbenim zapisom. Tudi skladatelj ne more predvide- 
ti in do konca določiti, kaj bo zaigranje njegovega dela, kaj bo v glasbenem življenju dejansko postalo in kakšen pomen bo dobilo. Od tod ni daleč do misli, da s samo partituro interpretativni akt še ni določen in da ni določen niti z glasbenim delom samim, saj si ni mogoče misliti, da bi glasbeno delo, ki je partitura le njegov zapis, že vsebovalo in predvidevalo vse možne izvedbe, kar pomeni tudi tole: Zgodovina interpretacije danega glasbenega dela ni pot h glasbenemu delu samemu in njegovi resnici. - To je razvidno tudi iz samega glasbenega življenja, saj ni videti, da bi se glasbeno interpretiranje približevalo določenemu v obrisih že razpoznavnemu cilju. - Zgodovina interpretacije danega glasbenega dela je lahko tudi pot, ki vodi stran od skladateljeve resnice, $v$ še nepoznano in neizkušeno daljavo.

Ali je pojmovanje glasbene interpretacije kot intencionalnega akta združljivo z glasbenim platonizmom? Zdi se, da ne, in sicer iz dveh razlogov. Prvič: Če so interpretacije dejanja, kot dejanja po svoji bitnosti ne morejo biti instance ideje. Razmislek o tem, ali je vendarle drugače, se pravi, da intencionalna dejanja morejo biti instance ideje, je pravzaprav tema iz zgodovine evropske metafizike, ki je tu ni mogoče načenjati, čeprav bi jo bilo vredno obravnavati prav z ozirom na vprašanja glasbenega interpretiranja. Drugič: Če glasbene interpretacije niso pot h glasbenemu delu, če vsebujejo lahko tudi nekaj, česar v glasbenem delu kot ideji ni predvideno in zaobseženo, med njimi in glasbenim delom ni mogoče vzpostaviti platonističnega odnosa med idejo in njenimi čutno zaznavnimi uresničitvami. Zanikanje platonističnega modela sicer še ne pomeni zanikanje povezave med glasbenim delom in njegovimi interpretacijami; odpira pa možnost novega razmisleka o njej. 